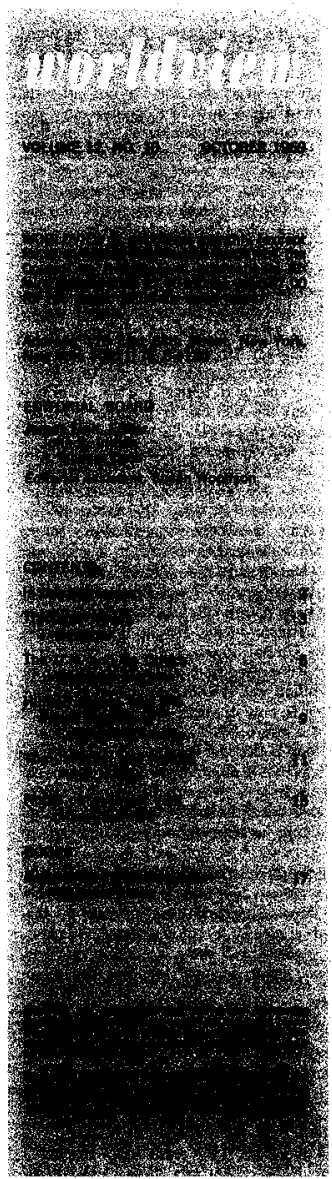

\section{TRACTABLE ISSUES}

The war continues, the moratorium is declared, President Nixon is undergoing a barrage of criticism for his handling of both domestic and foreign policies, and Dean Acheson. warns against "the attempt being made from so many sources to destroy Nixon."

Without glancing very far, there is enough material for several editorials here. Uncharacteristically we turn aside the monthly temptation to direct the large affairs of the world and turn instead to worldview and its sister publications (noted and described on our back cover). The staff of the Council on Religion and International Affairs had for years the belief that the activities it promoted and the publications it planned were directed to a small, elite audience. We have not departed from that idea, but the result of recent campaigns to introduce our publications to new readers has altered somewhat our idea of our natural audience. It includes a wider variety and, apparently, a greater number of people than we had thought. And a somewhat younger audience than we had thought. We find, for example, that our publications are going not only to the teaching faculties of universities and colleges but also to instructors in high schools. Not too surprising. What came as a welcome surprise is the increase in the number of students who turn to world view and our other publications.

We are, for example, announcing with this issue of worldview a new addition to our Special Studies series. William I. Barnds, a former member of the C.I.A. and presently Senior Research Fellow at the Council on Foreign Relations, has developed a thesis which previously appeared as a two-part article in worldview: The Right to Know, to Withhold and to Lie. It is now being published with commentaries by Wilson Carey McWilliams, a political scientist and journalist, the Reverend Daniel C. Maguire, a moral theologian at the Catholic University of America, and Paul W. Blackstock, a former intelligence research specialist who has written extensively in the field. The combined attack on the issues involved - if and when a government has a right to lie to or withhold information from its citizens, if and when the citizen has a right to demand such information - is both illuminating and provocative.

$\bullet$

The moral of these musings on the publications of CRIA? They are something you can do something about. For example, buy them as a gift for yourself or some other deserving person. If sent as a holiday gift, worldview offers special rates $-\$ 4.00$ for one gift subscription, $\$ 7.00$ for two, and $\$ 9.00$ for three and we will enclose, at your request, a gift card. And next month and the succeeding months we promise to.return to less tractable issues. 